\title{
Cerebellar Form of Progressive Multifocal Leukoencephalopathy in a Patient with Chronic Renal Failure
}

\author{
Tatsuro Irie, Masaharu Kasai, Nobuhiko Abe, Kazutoshi Seto, Tohru Naohara, Ken-ichi Kawamura, \\ Toshio Higa, Kimiaki Sano*, Hidehiro TaKaHASH* and Kazuo Nagashima*
}

\begin{abstract}
Progressive multifocal leukoencephalopathy (PML) developed in a 64-year-old woman who had undergone hemodialysis treatment due to chronic renal failure (CRF) for $6 \mathrm{yr}$. Her initial symptom was ataxia, and computed tomographic (CT) scan and magnetic resonance imaging (MRI) suggested a demyelinating disease of the cerebellum. Her cell-mediated immunity was impaired. At autopsy, the cerebellar disease was confirmed as PML by ultrastructual and immunohistochemical studies. Moreover, the JC type of papova virus infection was verified by Southern blot analysis.
\end{abstract}

(Internal Medicine 31: 218-223, 1992)

Key words: progressive multifocal leukoencephalopathy, cerebellar symptom, chronic renal failure, impaired cell-mediated immunity, southern blotting of DNA

\section{Introduction}

Progressive multifocal leukoencephalopathy (PML) is thought to be caused by a $\mathrm{JC}$ type of papova virus infection (1-3) that usually affects people with immune deficiency status such as lymphoma, leukemia, carcinomas, systemic lupus erythematosus, tuberculosis, acquired immune deficiency syndrome (AIDS) and so on $(4,5)$. On the other hand, in hemodialysis patients with chronic renal failure (CRF), infection is one of the most common complications, and impaired cell-mediated immunity is well known (6-9). But PML associated with chronic renal failure is rare $(3,4,10)$. The case reported here is a hemodialysis patient with CRF who developed a cerebellar form of PML.

\section{Case Report}

A 64-year-old woman, who had been treated with hemodialysis for CRF caused by chronic glomerulonephritis for 6 yr developed gait disturbance in March 1989. As her gait disturbance worsened over 1 month, she was admitted to our hospital on April 12, 1989.

Neurological examination revealed right hemiataxic gait, scanning speech, intention tremor, horizontal nystagmus, dysmetria and left oculomotor nerve paresis. No other neurological abnormalities were present.

The laboratory data are shown in Table 1 and the major abnormal findings were as follows: $\mathrm{Hb} 7.8 \mathrm{~g} / \mathrm{dl}$, decreased peripheral lymphocytes, total protein $5.4 \mathrm{~g} / \mathrm{dl}$, BUN $84 \mathrm{mg} / \mathrm{dl}$, creatinin $7.4 \mathrm{mg} / \mathrm{dl}$, blood sugar $122 \mathrm{mg} / \mathrm{dl}$. Tumor markers were within normal limits and viral studies including human immune deficiency virus and cytomegalovirus revealed no abnormality.

The cerebrospinal fluid (CSF) was under normal pressure; the fluid was clear with cells, $23 / 3(80 \%$, mononuclear, $20 \%$ polymorphonuclear); proteins $103 \mathrm{mg} / \mathrm{dl}$, sugar $91 \mathrm{mg} / \mathrm{dl}$, negative culture, negative oligoclonal band IgG and elevated myelin basic protein (Table 1).

A CT scan showed a lesion of low density in the right cerebellar peduncle and the white matter of the right cerebellar hemisphere without contrast enhancement and without mass effect (Fig. 1). MRI, which was performed at the same time, showed a high signal intensity lesion on the long SE, similar but clearer than that of the CT scan. The gray matter was not involved (Fig. 2). These CT and MRI findings suggested a demyelinating disease such as PML.

Immunological studies were performed and showed

From Department of Internal Medicine, Sapporo Hokuyu Hospital, Artificial Organ and Transplantation Hospital, Sapporo, *Department of The Second Pathology, University of Hokkaido, Sapporo

Received for publication May 2, 1990; Accepted for publication Junc 11, 1991

Reprint requests should be addressed to Tatsuro Irie, MD, Department of Internal Medicine, Sapporo Hokuyu Hospital, Higashisapporo 6-6, Shiroishi-ku, Sapporo 003, Japan 


\section{Multifocal Leukoencephalopathy in CRF}

Table 1. Laboratory Data

\begin{tabular}{|c|c|c|c|}
\hline \multicolumn{2}{|l|}{ Biochemistry } & \multicolumn{2}{|l|}{ Peripheral Blood } \\
\hline T.P & $5.4 \mathrm{~g} / \mathrm{dl}$ & $\mathrm{RBC}$ & $244 \times 10^{4} / \mu 1$ \\
\hline Alb & $67.5 \%(3.6 \mathrm{~g} / \mathrm{d} 1)$ & $\mathrm{Hb}$ & $7.8 \mathrm{~g} / \mathrm{dl}$ \\
\hline $\mathrm{r}-\mathrm{gl}$ & $10.6 \%$ & $\mathrm{Ht}$ & $22.7 \%$ \\
\hline T-bil & $0.5 \mathrm{mg} / \mathrm{dl}$ & WBC & $4800 / \mu \mathrm{l}$ \\
\hline T-chol & $111 \mathrm{mg} / \mathrm{dl}$ & \multicolumn{2}{|c|}{$[$ E $1 \%$, St $5 \%$, Seg $78 \%$ Lym $16 \%$, Mo $0 \%]$} \\
\hline GOT & $29 \mathrm{U}$ & \multirow{2}{*}{ PIt } & \multirow[t]{2}{*}{$17.3 \times 10^{4} / \mu 1$} \\
\hline GPT & $14 \mathrm{U}$ & & \\
\hline Alp & $16.6 \mathrm{KA}$ & \multicolumn{2}{|l|}{ Coagulation } \\
\hline $\mathrm{LDH}$ & $295 \mathrm{U}$ & $\mathrm{PT}$ & $56 \%$ \\
\hline ChE & $0.80 \Delta \mathrm{pH}$ & APTT & $85 \%$ \\
\hline$\gamma$-GTP & $61 \mathrm{U}$ & HPT & $42 \%$ \\
\hline CPK & $44 \mathrm{U}$ & Fbg & $313 \mathrm{mg} / \mathrm{dl}$ \\
\hline ZTT & $4.0 \mathrm{U}$ & FDP & $5.0 \mu \mathrm{g} / \mathrm{ml}$ \\
\hline TTT & $0.4 \mathrm{U}$ & & \\
\hline BUN & $84 \mathrm{mg} / \mathrm{dl}$ & \multicolumn{2}{|l|}{ Tumor marker } \\
\hline UA & $6.0 \mathrm{mg} / \mathrm{dl}$ & CEA & $4.0 \mathrm{ng} / \mathrm{ml}$ \\
\hline Creat & $7.4 \mathrm{mg} / \mathrm{dl}$ & $\mathrm{AFP}$ & $<3.0 \mathrm{ng} / \mathrm{ml}$ \\
\hline $\mathrm{Na}$ & $137 \mathrm{mEq} / 1$ & CA 19.9 & $33 \mathrm{U} / \mathrm{ml}$ \\
\hline $\mathrm{K}$ & $4.8 \mathrm{mEq} / \mathrm{l}$ & NSE & $6.1 \mathrm{ng} / \mathrm{ml}$ \\
\hline $\mathrm{Cl}$ & $98 \mathrm{mEq} / 1$ & & \\
\hline $\mathrm{Ca}$ & $4.0 \mathrm{mg} / \mathrm{dl}$ & \multicolumn{2}{|l|}{$\mathrm{CSF}$} \\
\hline $\mathrm{P}$ & $4.2 \mathrm{mg} / \mathrm{dl}$ & Pressure & $140 \mathrm{mmHg}$ \\
\hline FBS & $122 \mathrm{mg} / \mathrm{dl}$ & Clear & \\
\hline & & Xanth & $(-)$ \\
\hline Serological & & Cell & $23 / 3$ \\
\hline ESR & $38 \mathrm{~mm} / \mathrm{h}$ & \multicolumn{2}{|c|}{$($ Mo $80 \%$ Scg $20 \%)$} \\
\hline CRP & $3.1 \mathrm{mg} / \mathrm{dl}$ & Pandy & $(+)$ \\
\hline ASLD & 160 Todd & Prot & $103 \mathrm{mg} / \mathrm{dl}$ \\
\hline RA & $(-)$ & Sugar & $91 \mathrm{mg} / \mathrm{dl}$ \\
\hline Wa & $(-)$ & \multicolumn{2}{|l|}{ Cytology class I } \\
\hline Herpes simplex & $\times \operatorname{Ig} M \times 10>$ & \multicolumn{2}{|l|}{ Culture negative } \\
\hline Herpes zoster & $\operatorname{Ig} M \times 10>$ & Oligoclonal band IgG & $(-)$ \\
\hline $\mathrm{CMV}$ & $\operatorname{IgM} \times 10>$ & \multirow{3}{*}{ Myelin basic Prot } & \multirow[t]{3}{*}{$14.4 \mathrm{ng} / \mathrm{ml}$} \\
\hline HTLV I & $(-)$ & & \\
\hline HIV & $(-)$ & & \\
\hline
\end{tabular}
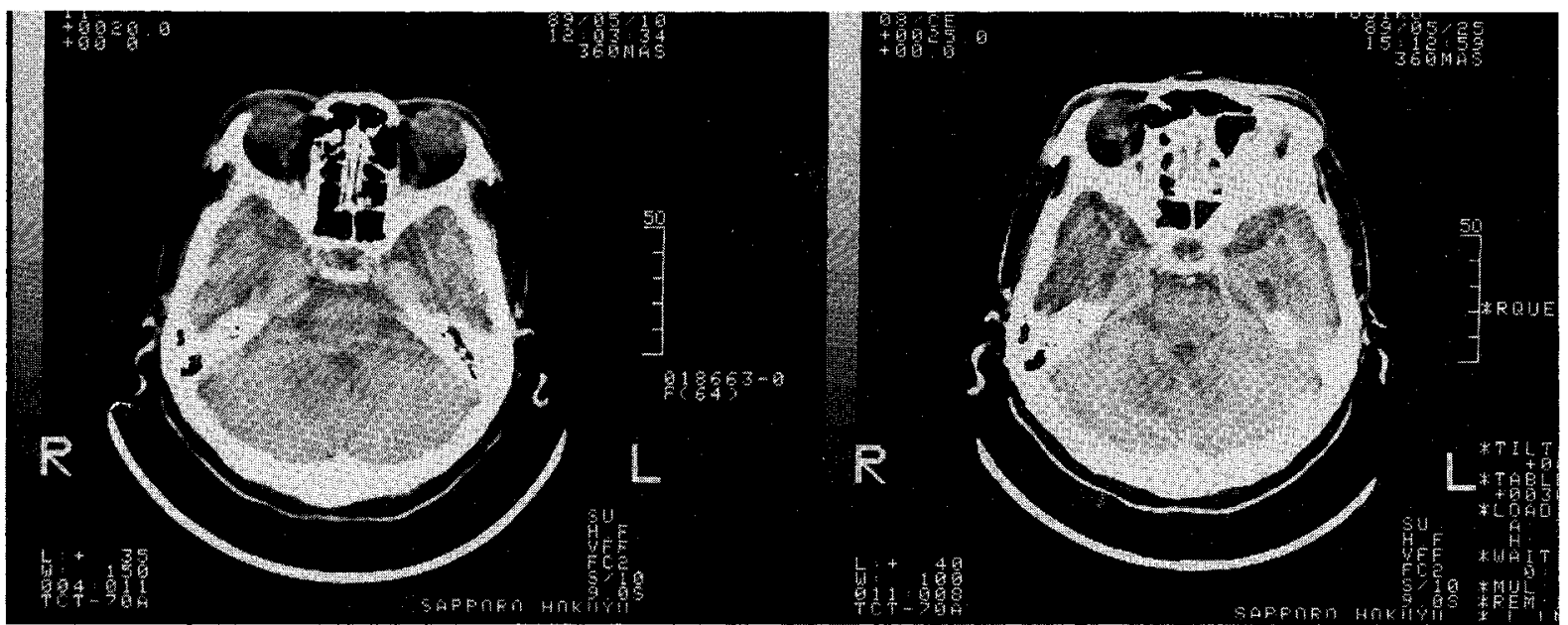

Fig. 1. Left: CT scan (plain) demonstrating a lesion of low density in the right cerebellar peduncle without mass effect. Right: CT scan (contrast enhancement) showing no contrast enhancement.

impaired cell-mediated immunity: negative tuberculin skin test, slightly decreased immunoglobulin production, low natural killer (NK) cell activity, and impaired blastogenesis of lymphocytes stimulated by phytohemag- glutinin (PHA), Con A and pokeweed mitogen (PWM). But the peripheral CD 4/8 lymphocyte ratio, which suggested the helper suppressor T-cell ratio, was normal (Table 2). 


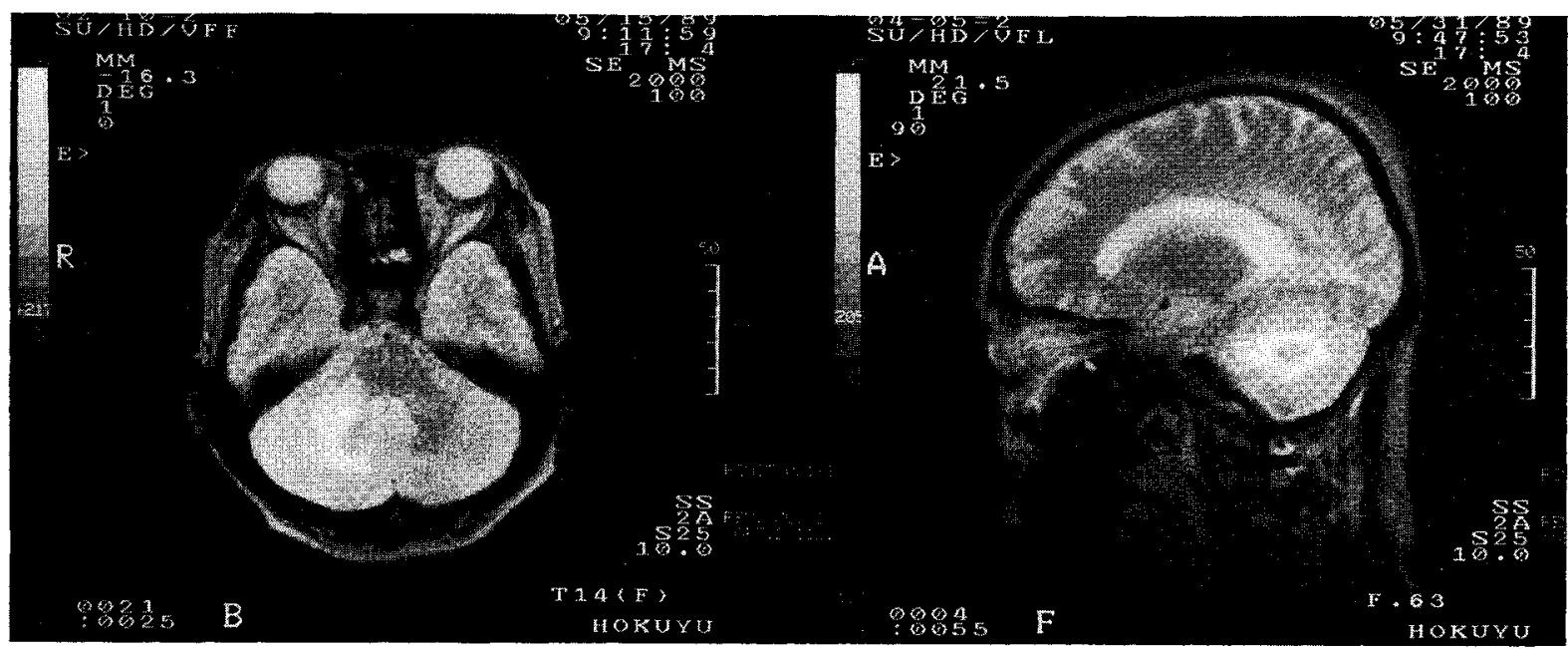

Fig. 2. MRI (long SE) Left: horizontal section, Right: sagittal section. MRI demonstrating high signal intensity lesion on the long SE scan.

Table 2. Immunological Data

\begin{tabular}{|c|c|c|c|}
\hline & $0 \times 0$ & \multicolumn{2}{|c|}{ NK activity } \\
\hline PPD & $\overline{1 \times 1}(-)$ & E:T 10: & $6.1 \%$ \\
\hline $\operatorname{IgG}$ & $944 \mathrm{mg} / \mathrm{dl}$ & E:T 20: & $7.6 \% \downarrow$ \\
\hline $\operatorname{IgA}$ & $156 \mathrm{mg} / \mathrm{dl}$ & PHA SI & $47.1 \downarrow$ \\
\hline $\operatorname{IgM}$ & $121 \mathrm{mg} / \mathrm{dl}$ & ConA SI & $42.8 \downarrow$ \\
\hline $\mathrm{IgE}$ & $94 \mathrm{U} / \mathrm{ml}$ & PWM SI & $27.8 \downarrow$ \\
\hline $\mathrm{T} / \mathrm{B}$ population & & CD 3 & $76.3 \%$ \\
\hline $\mathrm{T}$ cell & $77.8 \%$ & $\mathrm{CD} 4$ & $60.1 \%$ \\
\hline B cell & $16.2 \%$ & CD 8 & $17.6 \%$ \\
\hline Double marker cell & $0.8 \%$ & $\mathrm{CD} 4 / 8$ & 3.4 \\
\hline Null cell & $5.2 \%$ & & \\
\hline
\end{tabular}

The patient's neurological deficits worsened over the subsequent weeks with further impairment of the right oculomotor nerve, and the development of severe bilateral cerebellar ataxia. The patient was unable to walk after $6 \mathrm{wk}$. Shortly thereafter, pyramidal signs and sensory disturbance developed, and she became lethargic and decerebrate with the deterioration of neurological symptoms. CT scan findings worsened and sepsis developed at the end of June. She died of sepsis on July 3, 1989.

\section{Postmortem Findings}

The kidneys were markedly atrophied, the right weighing $55 \mathrm{~g}$, the left $60 \mathrm{~g}$, and consisted of alomst completely devastated glomeruli, which was compatible with the end stage of long-term hemodialysis. Pulmonary edema, hepatic congestion, follicular adenoma of the thyroid, cholelithiasis, and colonic mucosal hemorrhage were found, but none were predisposing for immune deficiency diseases.

The brain, weighing $1,100 \mathrm{~g}$, appeared normal externally, and was examined. On the cut surface, the cerebellar white matter and brainstem were grayish in color. Horizontal section of the brain showed multifocal coalescent demyelination mainly in the right cerebellum (Fig. 3). Microscopically, the myelin sheaths of the cerebellar white matter and brainstem were totally lost and replaced by reactive astrocytosis. Some bilateral pyramidal tracts were also involved at the pontine base. Some astrocytes were abnormal is shape and size with hyperchromatic large nuclei. There were numerous oligodendroglial cells which had enlarged hyperchromatic nuclei (Fig. 4). The cerebral cortex and white matter

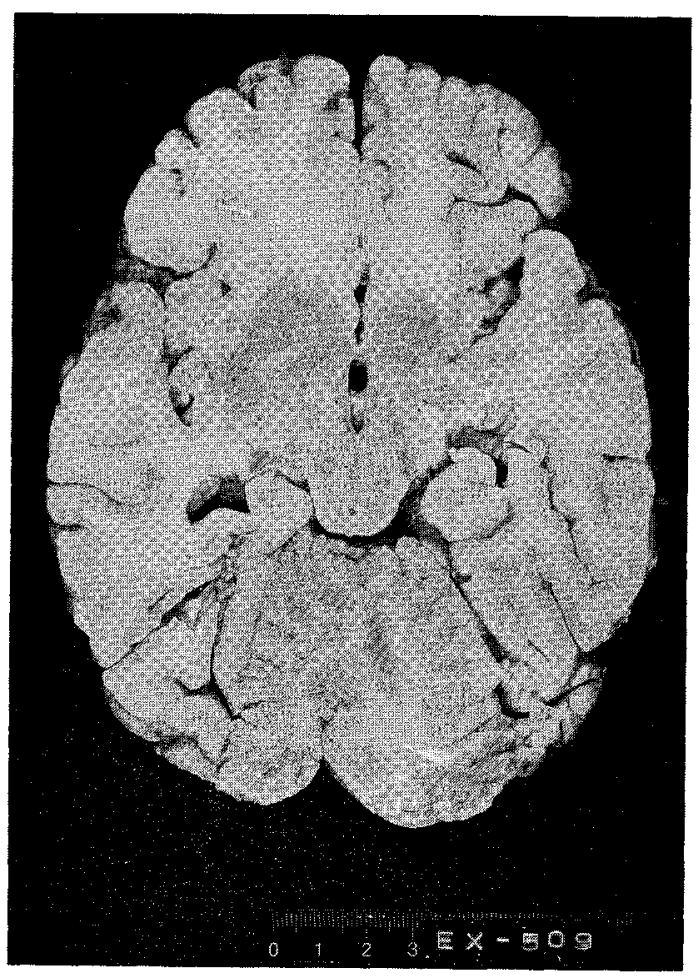

Fig. 3. Horizontal section of the brain through the cerebellar peduncle, showing multifocal and coalescent demyelination mainly in the right cerebellum (overview). 


\section{Multifocal Leukoencephalopathy in CRF}

were free from any demyelinating lesions.

Ultrastructural examination using formalin-fixed material disclosed that the enlarged nuclei were loaded with particles of approximately $40 \mathrm{~nm}$ in diameter, which was characteristic of papova virus (Fig. 5). Immunohistochemically, the enlarged oligodendroglial nuclei were positively stained with the anti-JC virus antibody $(3,10)$ (Fig. 6). These findings demonstrated that the cerebellar

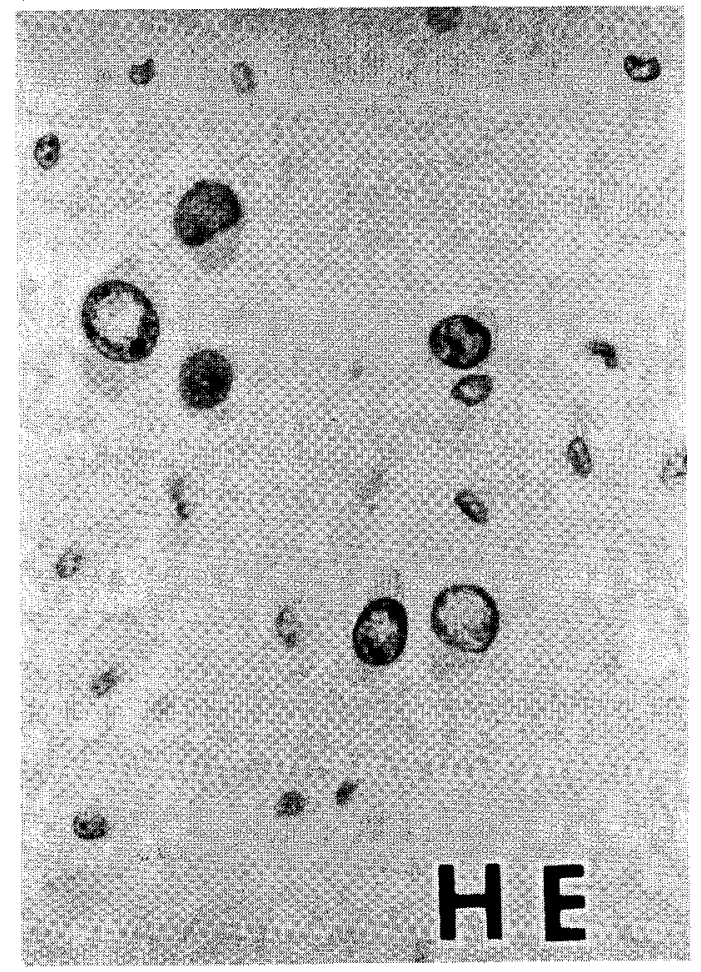

Fig. 4. HE staining $(\times 400)$ showing loss of the myelin sheath replaced by bizarre astrocytes and glial cells with enlarged hyperchromatic nuclei.

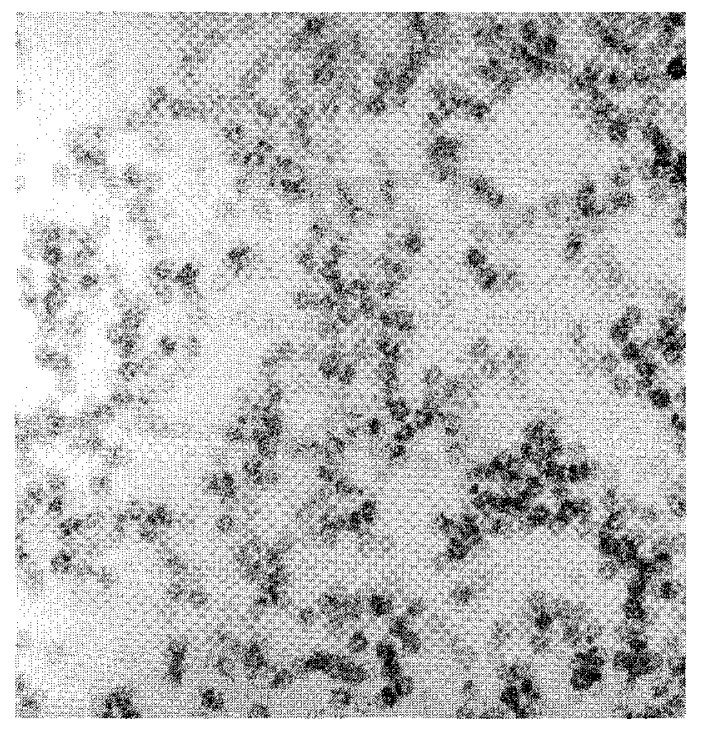

Fig. 5. Electron micrograph showing numerous virus particles of papova virus type in the enlarged nuclei. disease was PML and that the causative agent was the $\mathrm{JC}$ virus (11).

From the cerebellar tissue taken at autopsy and kept in the deep freezer at $-70^{\circ} \mathrm{C}$, the viral DNA was extracted, electrophoresed to agarose gel, and transferred

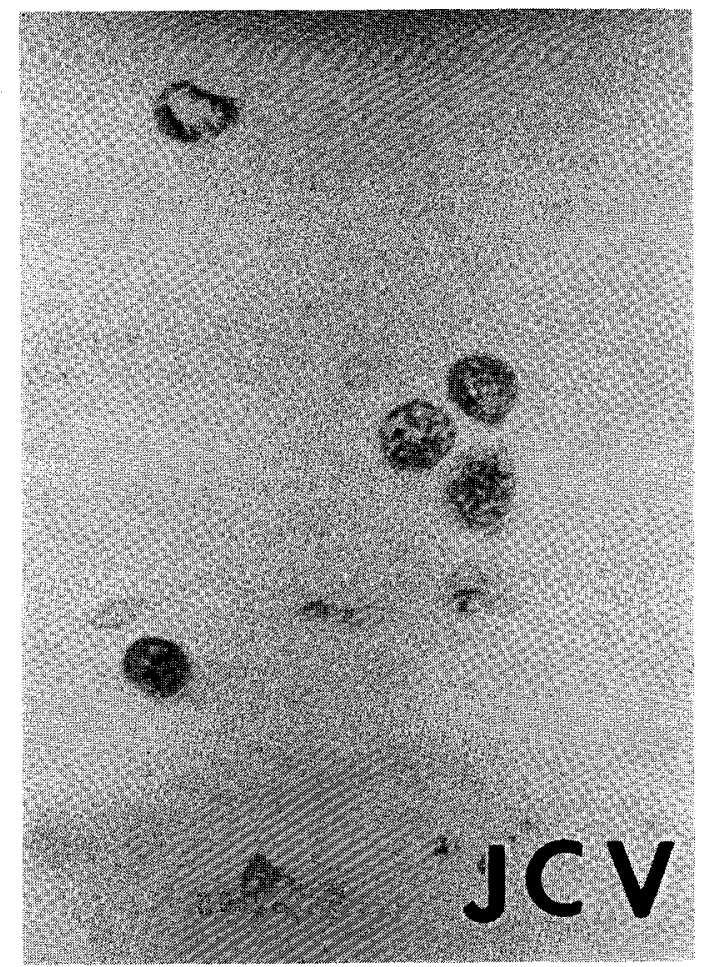

Fig. 6. Immunohistochemical study. The enlarged nuclei were positively stained with anti-JC virus antibody.

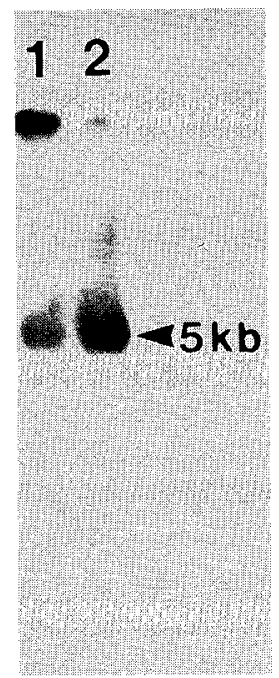

Fig. 7. Southern blot of DNA extracted from the cerebellar tissue hybridized with JC virus cDNA probe. Lane 1: Viral DNA crudely extracted from the brain. Lane 2: JC virus DNA extracted from pUC18 (Tokyo-1) used as positive control. Hybridization is seen at the level of $5 \mathrm{~kb}$ level (arrow), the molecular size of JC virus. 
to the nitrocellulose membrane. The transferred DNA was well hybridized with cDNA probe of the $\mathrm{JC}$ virus Tokyo-1 strain (Fig. 7) (12), which confirmed the JC virus infection at the molecular level. The viral DNA was successfully cloned into the plasmid pUC18 and the virus was designated as JC virus Sapporo- 1 strain (Sap-1). The data of the molecular analyses of the virus will be reported in a separate paper (13).

\section{Discussion}

In 1958, Åstrom introduced into the literature a hitherto unrecognized neuropathologic entity in human PML (14). A viral etiology was postulated on the basis of the presence of nuclear inclusion bodies and the association of this disorder with the diseases accompanied by an impaired immunological responsiveness (1). Now it is believed that PML is an opportunistic infection which involves the $\mathrm{JC}$ virus of the central nervous system (CNS) $(3,11)$. In our patient, electron microscopic findings and immunohistochemical study confirmed the $\mathrm{JC}$ virus infection. Furthermore, the viral DNA from the cellebellar tissue was extracted and the transferred DNA was well hybridized with the cDNA probe of the JC virus Tokyo-1 stain. Southern blotting analysis proved the $\mathrm{JC}$ virus infection at the molecular level.

The present patient showed predominant cerebellar involvement with minor cerebral lesions. Cerebellar symptoms are relatively rare as a first neurological deficit in PML, and cerebellar white matter as the main infected lesion is seldom reported $(10,11)$. Parr et al reviewed 10 cases, whose disease process was largely confined to the cerebellum and brainstem, and cerebellar symptoms occured at onset (15).

In the present case, MRI was more useful in the evaluation of the demyelinating lesions than the CT scan. Recently MRI has been used to evaluate demyelinating diseases including PML (16). The superiority of MRI in the detectability and usefulness of the clinical evaluation of PML has been reported (17-19). MRI seems to be more important for the evaluation of demyelinating diseases and diagnosing PML in early stages.

PML is known to affect persons with impaired immunological responsiveness (4). Malignant lymphoma and other lymphoreticular diseases, leukemia, tuberculosis, SLE, pharyngeal cancer, chronic thyroiditis, T-cell deficiency, sarcoidosis, rheumatoid arthritis, liver cirrhosis, and AIDS (5) have been reported as underlying disease for PML.

Patients with CRF often show impaired immunological responsiveness, and PML associated with CRF and long standing hemodialysis have been reported (10). But such cases are rare. According to the review of PML by Takahashi (4), 11 cases with CRF and/or renal transplantation have been reported. The present patient was treated with hemodialysis for CRF, and had no other disorders which caused impaired immunological responsiveness. It is quite unusual that in both the case of Matsubara et al (10) and in the present case, PML occurred in the cerebellar white matter.

Since infection is one of the most common complications in chronic hemodialysis patients, many investigations have reported impaired cell-mediated immunity in CRF, such as: peripheral blood lymphocytes are decreased (some of which can be improved after hemodialysis), mitogen-induced blastoid transformation using PHA, Con A and PWM is lower than normal, CD 4/8 ratio is often decreased, suggesting increased function of suppressor T-cell, the NK cell activity is impaired and the number of tuberculin skin test negatives is increased $(7-9,20)$.

In the present patient, the peripheral blood lymphocyte count was decreased, tuberculin skin test was negative, T/B population was within normal limits, NK cell activity was impaired, and induced blastoid transformation was impaired, but the $\mathrm{CD} 4 / 8$ ratio was normal. Although the reason why cell-mediated immunity is impaired in patients with CRF is not clearly understood yet, uremic toxins are thought to play an important role and some of them have been reported to be dialyzable (21). Further investigation is required.

Patients with CRF and chronic hemodialysis often develop CNS symptoms, for example uremic encephalopathy, hemodialysis encephalopathy, dialysis disequilibrium syndrome and cerebral vascular attack.

Although PML is a rare disease, the possibility of PML should be kept in mind if CRF patients with impaired immunity reveal CNS signs and symptoms. MRI detection and brain biopsy if possible would be recommended for early diagnosis of PML. It must be stressed, however, that PML in CRF patient with a main cerebellar lesion is very rare.

\section{References}

1) ZuRhein GH, Chou SM. Particles resembling papova viruses in human cerebral demyelinating disease. Science 148: 1477, 1965.

2) Amin AF, A Julio M. Primary progressive multifocal leukoencephalopathy. A central nervous system disease caused by a slow virùs. Arch Neurol 27: 357, 1972.

3) Nagashima K, Yamaguchi K, Yasui K, ct al. Progressive multifocal leuko-encephalopathy. Neuropathology and virus isolation. Acta Pathol Jpn 31: 953, 1981.

4) Takahashi A. Progressive multifocal leukoencephalopathy. Clin Neurosci 2: 690, 1984

5) Miller J, Barrett RE, Britton CB, et al. Progressive multifocal leukoencephalopathy in a male homosexual with T-cell immune deficiency. N Engl J Med 307: 1436, 1983.

6) Fujita Y. Immune competence in chronic hemodialysis patients. Kidney Dialysis 5: 281, 1978.

7) Dobbelstein H. Immune system in uremia. Nephron 17: 409, 1976.

8) Hoy WE, Cestero RVM, Freiman RB, et al. Deficiency of T and $B$ lymphocytes in uremia subjects and partial improvement with maintenance hemodialysis. Nephron 20: 182, 1978. 


\section{Multifocal Leukoencephalopathy in CRF}

9) Sowa N. Serial changes in cell-mediated immunity in chronic dialysis patients. J Jpn Soc Dial Ther 20: 975, 1987.

10) Matsubara $O$, Nakagawa $S$, Shinoda $T$, et al. Progressive multifocal leukoencephalopathy associated with prolonged hemodialysis treatment. Virchows Arch [A] 403: 301, 1984.

11) Nagashima, K. Yamaguchi K, Nakase $H$, ct al. Progressive multifocal leukoencephalopathy. A case report and review of the literature. Acta Pathol Jpn 32: 333, 1982.

12) Matsuda $M$, Jona $M$, Yasui $K$, et al. Genetic characterization of JC virus Tokyo-1 strain, a variant oncogenic in rodents. Virus Res 7: 159, 1987.

13) Takahashi H, Yogo Y, Fumita Y, et al. Molecular charactcrization of a JC virus (Sap-1) clone derived from a cerebellar form of progressive multifocal leukoencephalopathy. Acta Neuropathol. 83: (in press), 1992.

14) Åstrom KE, Mancall EL, Richardson EP, et al. Progressive multifocal leukoencephalopathy. A hitherto unrecognized complication of chronic lymphatic leukemia and Hodgkin's disease. Brain 81: 93, 1958.

15) Parr $\mathbf{J}$, Horoupian DS, Winkelman AC, et al. Cerebellar form of progressive multifocal leukocncephalopathy (PML). Can J Neurol Sci 6: 123, 1979.

16) Drayer BP, Barvet L, et al. Progressive multifocal leukoencephalopathy and magnetic resonance imaging and CT scan in multiple sclerosis. Ann NY Acad Sci 294, 1985.

17) Lcvy JD, Cottingham KL, Cambell RJ, et al. Progressive multifocal leukoencephalopathy and magnetic resonance imaging. Ann Neurol 19: 399, 1986.

18) Doi S, Tashiro K, Moriwaka F, et al. Progressive multifocal leukoencephalopathy (PML)-the sequential change in MRI and CT scan findings-. Prog CT 9: 53, 1987.

19) Tashiro K, Doi S, Moriwaka F, et al. Progressive multifocal leukoencephalopathy with magnetic resonance imaging verifilation and therapeutic trials with infection. J Neurol 234: 427, 1987.

20) Nakhla LS, Goggin MJ. Lymphocyte transformation in chronic renal failure. Immunology 24: 229, 1973.

21) Kamata, K, Okubo M. Hypoimmunity of non-dialyzed uremic patients, in special reference to disturbed humoral immunity and the effect of dialysis. Kitasato Med 12: 651, 1982. 